\title{
PARTISIPASI MASYARAKAT DALAM PROSES PEMBENTUKAN UNDANG-UNDANG YANG RESPONSIF
}

\author{
(Community Participation in order to Create the Responsive Law)
}

\author{
Rahendro Jati \\ Badan Pembinaan Hukum Nasional - Kementerian Hukum dan HAM RI \\ Jalan Mayjen Sutoyo Nomor 10 Jakarta Timur \\ Email: rahendrojati@yahoo.com
}

Naskah diterima: 5 Desember 2012; revisi: 11 Desember 2012; disetujui: 13 Desember 2012

\begin{abstract}
Abstrak
Partisipasi masyarakat merupakan wujud adanya relasi antara masyarakat dengan DPR dan Pemerintah dalam proses pembentukan undang-undang. Agar hubungan tersebut dapat memberikan manfaat bagi penciptaan undang-undang yang responsif, maka partisipasi masyarakat harus ada pada setiap tahapan pembentukan undang-undang. Tidak hanya berupa hak yang diformalkan dalam bentuk aturan saja, tetapi penyampaian aspirasi masyarakat tersebut secara nyata harus dapat dilaksanakan dan direspon oleh pembentuk undang-undang. Tulisan ini akan membahas mengapa paratisipasi masyarakat diperlukan dalam pembentukan peraturan perundang-undangan; serta bagaimana proses pembentukan undang-undang yang melibatkan partisipasi masyarakat sehingga melahirkan undang-undang yang responsif. Dengan menggunakan pendekatan sosio-legal dengan metode juridis normatif terlihat bahwa partisipasi masyarakat merupakan wujud dari pelaksanaan asas keterbukaan yang merupakan salah satu asas dalam pembentukan peraturan perundangundangan yang akan memberikan manfaat penting dalam hal efektivitas pemberlakuan peraturan perundang-undangan di dalam masyarakat. Secara formal, proses untuk mewujudkan produk undang-undang yang responsif ini sudah memungkinkan, tetapi penerimaan aspirasi masyarakat secara substansi oleh para pembentuk undang-undang untuk mewujudkan undang-undang yang responsif sangat tergantung pada sikap dan cara pandang pembentuk undang-undang dengan berbagai kepentingan yang ada didalamnya. Untuk itu perlu adanya kesadaran dari masyarakat dan pembentuk undang-undang mengenai relasi yang terjadi diantara keduabelah pihak dalam pembentukan undang-undang.

Kata kunci: partisipasi masyarakat, pembentukan peraturan perundang-undangan, undang-undang responsif.
\end{abstract}

\begin{abstract}
Community Participation is a form of the relationship between the public with Parliament and the Government in the legislative process. In order to create the benefit of responsive law, then there should be public participation at every stage of legislative process. It's not only formalized the rights in the form of rules, but also delivery of real aspirations to be feasible and responded to by the legislators. This paper will discuss why public participation is necessary in the process of formating legislation, as well as how the process of establishing laws that involve community participation to make responsive laws. By using a socio-legal approach and normative juridical method shows that public participation is a form of implementation of the principle of openness that is one of the principles in the formating legislation. It will provide significant benefits in terms of the effectiveness of the application of laws in society. Formally, the process to create responsive legislation products is already possible, but the acceptance of the people's aspirations in substance by the law makers to realize the responsive legislation is highly depend on the attitudes and perspectives of legislators. For that it need the awareness of the public and legislators about the relationships that occur between the two parties in the formating legislation.
\end{abstract}

Keywords: community participation, establishment of legislation, responsive laws. 


\section{A. Pendahuluan.}

Sebagai negara hukum, segala aspek kehidupan dalam bidang kemasyarakatan, kebangsaan, dan kenegaraan termasuk pemerintahan harus berdasarkan atas hukum yang sesuai dengan sistem hukum nasional. ${ }^{1}$ Karena prinsip negara hukum yang dianut Indonesia adalah negara hukum modern, yaitu Negara Hukum Pancasila, maka maka fungsi peraturan perundang-undangan bukanlah hanya memberi bentuk kepada endapan nilainilai dan norma-norma yang hidup dalam masyarakat dan juga bukan hanya sekedar fungsi negara di bidang pengaturan, namun peraturan perundang-undangan adalah salah satu metoda dan instrumen ampuh yang tersedia untuk mengatur dan mengarahkan kehidupan masyarakat menuju cita-cita yang diharapkan. Dalam negara hukum modern, peraturan perundang-undangan diharapkan mampu untuk "berjalan didepan" memimpin dan membimbing perkembangan serta perubahan masyarakat. ${ }^{2}$ Maria Farida menyatakan bahwa di dalam negara yang berdasar atas hukum modern, tujuan utama dari pembentukan undang-undang bukan lagi menciptakan kodifikasi bagi norma-norma dan nilai-nilai yang sudah mengendap dalam masyarakat, akan tetapi tujuan utama pembentukan undangundang adalah menciptakan modifikasi atau perubahan dalam kehidupan masyarakat. ${ }^{3}$ Yuliandri menyatakan bahawa "legal policy" yang dituangkan dalam undang-undang, menjadi sebuah sarana rekayasa sosial, yang memuat kebijaksanaan yang hendak dicapai pemerintah, untuk mengarahkan masyarakat menerima nilai-nilai baru. ${ }^{4}$ Sedangkan Hattu menyatakan bahwa dalam negara hukum modern memerlukan pembentukan peraturan perundang-undangan yang berfungsi sebagai instrumen untuk memberi, mengatur, membatasi sekaligus mengawasi pelaksanaan tugas dan wewenang Pemerintah dan menjamin hak-hak masyarakat. ${ }^{5}$

Dengan cara pembentukan hukum melalui modifikasi, menurut Maria Farida terdapat beberapa keuntungan antara lain bahwa pembantukan hukum tidak memakan waktu yang lama dan hukum dapat selalu berada di depan. Walaupun menurutnya kadangkadang hukum yang dirumuskan dengan cara modifikasi tersebut kurang sesuai dengan kehendak masyarakat, akan tetapi apabila pembentukan undang-undangnya dilakukan dengan cara modifikasi yang baik dan disertai dengan kajian yang mencukupi, maka hukum

\footnotetext{
Penjelasan Umum UU No. 12 Tahun 2011 tentang Pembentukan Peraturan Perundang-Undangan.

2 Tim Pengajar Teori Perundang-Undangan Fakultas Hukum Universitas Indonesa, Teori Perundang-Undangan, dalam laporan akhir Penyusunan Naskah akademik RUU Perubahan Atas UU No. 10 Tahun 2004 tentang Pembentukan Peraturan Perundang-Undangan, Badan Pembinaan Hukum Nasional, 2009, hlm. 12.

3 Maria Farida Indrati, Ilmu Perundang-Undangan: Jenis, Fungsi dan Materi Muatan, (Yogyakarta: Penerbit Kanisius, 2002), hlm. 2. Terhadap hal ini Hamid S. Attamimi menyatakan bahwa untuk menghadapi perubahan dan perkembangan kebutuhan masyarakat yang semakin cepat, sudah bukan saatnya mengarahkan pembentukan hukum melalui penyusunan kodifikasi. Karena pemikiran tentang kodifikasi hanya akan menyebabkan hukum selalu berjalan dibelakang dan bukan tidak mungkin selalu ketinggalan zaman.

4 Yuliandri, Asas-Asas Pembentukan Peraturan Perundang-Undangan yang Baik: Gagasan Pembentukan UndangUndang Berkelanjutan, (Jakarta: Rajawali Press, 2011), hlm. 1.

Hendrik Hattu, Tahapan Undang-Undang Responsif, Jurnal Mimbar Hukum, Vol. 23, No. 2, Juni 2011, hlm. 406, diakses dari http://dosen.narotama.ac.id/wp-content/uploads/2012/02/tahapan-undang-undang-responsif. pdf
} 
tersebut akan dapat menjadi pedoman dan menjadi panglima serta dapat berlaku sesuai dengan perkembangan masyarakat. ${ }^{6}$ Walaupun lebih cocok dengan perkembangan saat ini, akan tetapi pendapat Maria Farida mengenai kurang sesuainya perumusan hukum dengan kehendak masyarakat melalui mekanisme modifikasi dalam pembentukan undang-undang harus disikapi secara bijaksana. Sebagai pihak yang akan merasakan pelaksanaan undang-undang, kehendak masyarakat dalam perumusan substansi dan norma dalam penyusunan undangundang harus mendapat mendapat perhatian yang lebih dari pembentuk undang-undang. Hal ini karena dalam pelaksanaan berlakunya suatu norma, selain didasarkan karena adanya daya laku (validity) juga didasarkan karena adanya daya guna (efficacy) dari norma tersebut. Dalam hal ini dapat dilihat apakah suatu norma yang ada dan berdaya laku itu berdaya guna secara efektif atau tidak. Atau dengan kata lain apakah norma itu ditaati atau tidak.? $\mathrm{Hal}$ ini menjadi penting karena dalam proses pembentukan undang-undang, terjadi usaha untuk mentransformasikan norma-norma yang diinginkan oleh lembaga pembentuk undangundang kepada masyarakat dalam suatu bentuk aturan hukum. Pembentuk undang-undang sejak awal proses perancangan, telah dituntut agar undang-undang yang dihasilkan mampu memenuhi berbagai kebutuhan. Pertama, mampu dilaksanakan; kedua, dapat ditegakkan; ketiga, sesuai dengan prinsip-prinsip jaminan hukum dan persamaan hak-hak sasaran yang diatur; dan keempat, mampu menyerap aspirasi masyarakat. ${ }^{8}$ Kondisi ini menunjukkan bahwa pembentukan undang-undang tidak hanya sebatas melaksanakan proses formal, tetapi juga harus berpedoman pada asas-asas pembentukan peraturan perundang-undangan yang baik sehingga kualitas undang-undang yang dibentuk sesuai dengan tujuan yang diinginkan.

Salah satu elemen yang penting untuk menghasilkan produk hukum yang responsif adalah partisipasi masyarakat. Menurut Nonet danSelznick, pentingnya peran masyarakatdalam pembentukan produk hukum harus terlihat pada proses pembentukannya yang partisipatif dengan mengundang sebanyak-banyaknya partisipasi semua elemen masyarakat, baik dari segi individu ataupun kelompok masyarakat. Selain itu juga harus bersifat aspiratif yang bersumber dari keinginan atau kehendak dari masyarakat. Artinya produk hukum tersebut bukan kehendak dari penguasa untuk melegitimasikan kekuasaannya. ${ }^{9}$ Pembahasan tentang partisipasi publik berkaitan erat dengan hubungan atau relasi masyarakat dengan negara dalam pembentukan kebijakan yang akan dikeluarkan negara untuk mengatur warganya. Lothar Gundling ${ }^{10}$ mengemukakan beberapa alasan tentang perlunya peran serta masyarakat dalam penyusunan suatu kebijakan, yaitu:

Maria Farida, Op.Cit. hlm. 6.

Ibid.

8 Lihat Saifuddin Proses Pembentukan UU: Studi Tentang Partisipasi Masyarakat dalam Proses Pembentukan UU, Jurnal Hukum No. Edisi Khusus Vol. 16 Oktober 2009, hlm. 96, diakses dari http://law.uii.ac.id/images/stories/ Jurnal\%20Hukum/5\%20Saifudin.pdf

9 Nonet dan Selznick, Law and Society in Transition: Toward Rensponsive Law, dalam A. Ahsin Thohari, Reorientasi Fungsi legslasi Dewan Perwakilan: Upaya Menuju Undang-Undang Responsif, Jurnal Legislasi Indonesia, Vol. 8 No. 4, (Jakarta: Direktorat Jenderal Peraturan Perundang-Undangan, 2011), hlm. 569.

10 Yuliandri, Op.Cit, hlm. 188. 
1. memberi informasi kepada pemerintah.

2. meningkatkan kesediaan masyarakat untuk menerima keputusan.

3. membantu perlindungan hukum.

4. mendemokrasikan pengambilan keputusan.

Sedangkan tujuan dasar dari peran serta masyarakat adalah untukmenghasilkan masukan dan persepsi yang berguna dari warga negara dan masyarakat yang berkepentingan (publik interests) dalam rangka meningkatkan kualitas pengambilan keputusan. Hal ini karena dengan melibatkan masyarakat yang terkena dampak akibat kebijakan dan kelompok kepentingan (interest grups), maka para pengambil keputusan akan dapat menangkap pandangan, kebutuhan dan penghargaan dari masyarakat dan kelompok tersebut, untuk kemudian menuangkannya ke dalam satu konsep. ${ }^{11}$

Dalam proses pembentukan undang-undang yang partisipatif, terkandung dua hal yang saling mengkait, yaitu proses dan substansi. Proses adalah mekanisme dalam pembentukan undang-undang yang harus dilakukan secara transparan sehingga masyarakat dapat berpartisipasi memberikan masukan-masukan dalam mengatur suatu persoalan. Substansi adalah materi yang akan diatur harus ditujukan bagi kepentingan masyarakat luas sehingga menghasilkan suatu undang-undang yang demokratis berkarakter responsif.

UU No. 12 Tahun 2011 tentang Pembentukan Peraturan Perundang-Undangan telah memberi hak secara lisan dan/atau tertulis kepada masyarakat untuk ikut berpartisipasi dalam pembentukan peraturan perundang-undangan.
Hanya saja dalam pelaksanaannya, hak ini belum dapat dijalankan secara baik. Keterbatasan akses masyarakat dan keengganan dari pembentuk undang-undang untuk memberi ruang baik secara formal maupun substansi kepada masyarakat tampaknya masih menjadi kendala dalam pelaksanaan partisipasi masyarakat.

\section{B. Permasalahan.}

Dari uraian diatas dirumuskan permasalahan sebagai berikut:

1. Mengapa paratisipasi masyarakat diperlukan dalam pembentukan peraturan perundang-undangan?

2. Bagaimana proses pembentukan undang-undang yang melibatkan partisipasi masyarakat sehingga melahirkan undangundang yang responsif?

\section{Metode Penelitian.}

Berdasarkan permasalahan diatas, penelitian ini merupakan suatu penelitian yuridis normatif ${ }^{12}$ dengan cara meneliti bahan pustaka atau data sekunder dan dimaksudkan untuk menjelaskan berbagai peraturan perundang-undangan yang terkait dengan partisipasi masyarakat dan pembentukan peraturan perundangundangan. Sedangkan pendekatan yang dipakai adalah pendekatan sosio hukum sehingga dapat memiliki prespektif yang lebih luas dengan melihat partispasi masyarakat dalam hubungannya dengan sistem sosial, politik dan ekonomi masyarakat. 


\section{REECHTSVINDING}

\section{Pembahasan.}

\section{Pentingnya Partisipasi Masyarakat dalam pembentukan peraturan perundang-undangan.}

Partisipasi dalam kamus besar bahasa Indonesia adalah perihal turut berperan serta dalam suatu kegiatan; keikutsertaan; peran serta. Sedangkan masyarakat adalah sejumlah manusia dalam arti seluas-luasnya dan terikat oleh suatu kebudayaan yang mereka anggap sama. ${ }^{13}$ Masyarakat dalam pengertian UU No. 12 Tahun 2011 adalah orang perseorangan atau kelompok orang yang mempunyai kepentingan atas substansi rancangan undang-undang. ${ }^{14}$

Istilah partisipasi masyarakat banyak dijumpai dalam beberapa terminologi, beberapa diantaranya menyebutkan peran serta masyarakat atau partisipasi public. ${ }^{15}$ Oleh Hutington dan Nelson, partisipasi publik didefinisikan sebagai activity by private citizens designed to influence government decision making (partisipasi publik menjadi salah satu alat dalam menuangkan nilai-nilai yang berkembang dimasyarakat untuk dituangkan dalam suatu peraturan). ${ }^{16}$ Pusat Studi Hukum dan Kebijakan mendefinisikan partisipasi sebagai keikutsertaan masyarakat, baik secara individual maupun kelompok, secara aktif dalam penentuan kebijakan publik atau peraturan. ${ }^{17}$
Dalam konteks hubunganya dengan tata pemerintahan yang baik ((good governance), maka partisipasi merujuk pada keterlibatan aktf masyarakat dalam pengambilan keputusan yang berhubungan dengan penyelenggaraan pemerintahan. Partisipasi masyarakat mutalk diperlukan agar penyelenggara pemerintahan dapat lebih mengenal warganya berikut cara pikir dan kebiasaan hidupnya, masalah yang dihadapinya, cara atau jalan keluar yang disarankan, apa yang dapat disumbangkan dalam memecahkan maslaha yang dihadapi. ${ }^{18}$ Masih dengan konteks yang sama, UNDP mengartikan partisipasi sebagai keterlibatan masyarakat dalam pembuatan keputusan baik secara langsung maupun tidak langsung melalui lembaga perwakilan yang dapat menyalurkan aspirasinya. Partisipasi tersebut dibangun atas dasar kebebasan bersosialisasi dan berbicara serta berpartisipasi secara konstruktif. ${ }^{19}$

Seringkali timbul anggapan bahwa dalam suatu negara yang telah menganut sistem perwakilan tidak ada keharusan untuk melaksanakan bentuk-bentuk partisipasi masyarakat karena para wakil rakyat telah bertindak untuk kepentingan rakyat. Menurut Gibson, ${ }^{20}$ pemikiran semacam ini dapat didekati dengan dua teori yaitu teori demokrasi elit (elite democracy) dan teori demokrasi partisipatif

lihat http://www.kbbi.web.id/

Lihat UU No. 12 Tahun 2011 Pasal 96 ayat (3) beserta penjelasannya.

Yuliandri, Op.Cit. hlm. 185.

Ibid.

Ibid.

18 Sekretariat Tim Pengembangan Kebijakan Nasional Tata Kepemerintahah yang baik, Kementerian Perencanaan Pembangunan Nasional/Bappenas, Penerapan Tata Keperintahan yang Baik, Jakarta, 2007 diakses dari http:// goodgovernance.bappenas.go.id/gg/file/publications/buku_hijau.pdf

19 Hetifah Sj Sumarto, Inovasi, Partisipasi dan Good Governance, dalam Griadhi dan Sri Utari, Partisipasi Masyarakat dalam Pembentukan Peraturan Daerah, http://ojs.unud.ac.id/ index.php/kerthapatrika/article/ view/3257/2336

20 R.B Gibson, The Value Participation, dalam Yuliandri, Op.Cit, hlm. 188-190. 
(participatory democracy). Teori demokrasi elit (elite democracy) menjelaskan bahwa:

"...ruang lingkup demokrasi adalah sebatas keikutsertaan warga dalam pemilihan umum yang bebas dan jujur untuk mengisi jabatan politis di pemerintahan dan badan legislatif. Jika warga telah melaksanakan hak pilihnya dalam pemilihan umum yang bebas dan jujur, makauntukseterusnyawargamempercayakan penyelenggaraan pemerintahan kepada mereka yang terpilih, sedangkan pengawasan terhadap pemerintahan dilakukan oleh mereka yang terpilih menjadi anggota badan legislatif. Teori elit demokrasi mengutamakan kestabilan dan kewenangan pemerintah. Adalah tugas anggota-anggota badan legislatif untuk mengawasi pemerintah dalam membuat kebijakan dan keputusan adminsitrasi sehingga tidak menyimpang dari kepentingan umum para warga pemilih. Terbatasnyaperanserta(masyarakat)menurut padangan teori elit demokrasi didasarkan pada asumsi, bahwa warga cenderung lebih memikirkan diri sendiri (selfish) guna memenuhi kepuasan (satisfaction) dirinya sehingga dalam masyarakat seringkali terjadi perbedaan kepentingan yang dapat menimbulkan gangguan sosial. Oleh sebabitu pemerintahlah yang mempunyai letigimasi untuk bertindak atasnama masyarakat dan menghindari konflik tuntutan dan ketidakstabilan masyarakat."

Sebaliknya menurut teori demokrasi partisipatif (participatory democracy), dalam kaitannya dengan keberadaan peran serta masyarakat, menyatakan:

"...warga baik secara perorangan maupun secara kelompok bukanlah sematamata konsumen kepuasan (consumers of satisfaction), tetapi membutuhkan kesempatan dan dorongan untuk pengungkapan dan pengembangan diri (self expression and development). Para penganut teori "participatory democracy" monolak asumsi bahwa warga satu sama lain selalu dalam keadaan konflik kepentingan, tetapi sebaliknya berpandangan bahwa hakikat dari kepribadianmanusiaadalahsalingmelengkapi dalam kehidupan bersama (collective life) sehingga orang satu sama lain mampu menyelaraskan antara kepentingan pribadi (individual interests) dengan kepentingan bersama (social interests) melalui cara-cara yang dapat diterima. Menurut penganut teori demokrasi partisipasi, hakikat demokrasi adalah untuk menjamin bahwa keputusankeputusan yang dibuat oleh pemerintah dengan menyertakan warga yang mungkin terkena dampak dari keputusan-keputusan itu. Oleh sebab itu, pengertian demokrasi adalah memberi dorongan untuk berperan serta dalam pembuatan keputusankeputusan yang mempengaruhi kehidupan mereka. Dengan demikian, teori ini tidak hanya ingin mewujudkan pemerintahan yang demokratis (democratic governments) tetapi juga masyarakat yang demokratis (democratics societies).

Terkait dengan hal tersebut, Koesnadi Hardjasoemantri ${ }^{21}$ menyatakan bahwa:

1. demokrasi dengan sistem perwakilan adalah satu bentuk demokrasi, bukan satusatunya;

2. sistem perwakilan tidak menutup bentukbentuk demokrasi langsung; dan

3. bukanlah warga masyarakat, sekelompok warga masyarakat atau organisasi yang sesungguhnya mengambil keputusan. Mereka hanya berperan serta dalam tahaptahap persiapan pengambilan keputusan.

Partisipasi masyarakat dalam pembentukan peraturan perundang-undangan adalah merupakan wujud dari pelaksanaan asas keterbukaan yang merupakan salah satu asas dalam pembentukan peraturan perundangundangan yang baik. Penjelasan Pasal 5 huruf g UU No. 12 Tahun 2011 menyatakan bahwa

21 Koesnadi Hardjasoemantri, Hukum Tata Lingkungan, dalam Yuliandri, Ibid, hlm. 190. 


\section{$\mathrm{R}_{\text {juknaL }}^{\text {juTSVINDING }}$}

Media Pembinaan Hukum Nasional

"Yang dimaksud dengan "asas keterbukaan" adalah bahwa dalam Pembentukan Peraturan Perundang-undangan mulai dari perencanaan, penyusunan, pembahasan, pengesahan atau penetapan, dan pengundangan bersifat transparan dan terbuka. Dengan demikian, seluruh lapisan masyarakat mempunyai kesempatan seluas-luasnya untuk memberikan masukan dalam Pembentukan Peraturan Perundang-Undangan. Sejalan dengan hal tersebut Hadjon mengemukakan bahwa konsep partisipasi masyarakat berkaitan dengan konsep keterbukaan. Dalam artian, tanpa keterbukaan pemerintahan tidak mungkin masyarakat dapat melakukan peranserta dalam kegiatan-kegiatan pemerintahan. Lebih lanjut Hadjon menyatakan bahwa keterbukaan, baik "openheid" maupun "openbaar-heid" sangat penting artinya bagi pelaksanaan pemerintahan yang baik dan demokratis. ${ }^{22}$

Sebagai prasyarat untuk membentuk peraturan perundang-undangan yang baik, partisipasi masyarakat akan memberikan manfaat penting yaitu peraturan perundangundangan akan memiliki kelebihan dalam hal efektivitas keberlakuan di dalam masyarakat. KoesnadiHardjasoemantri ${ }^{23}$ berpendapatbahwa peran serta masyarakat dapatlah dipandang untuk membantu negara dan lembagalembaganya guna melaksanakan tugas-tugas dengan cara yang lebih dapat diterima dan berhasil guna. Selain itu, partisipasi masyarakat akan menciptakan masyarakat yang lebih inklusif dan equitable serta memperkuat lembaga demokrasi. Manfaat yang akan diperoleh dengan partisipasi masyarakat dalam pembentukan peraturan perundang-undangan adalah ${ }^{24}:$ 1) meningkatkan letigimasi dan kualitas peraturan perundang-undangan yang dihasilkan; 2) meningkatkan peluang untuk keberhasilan dalam penerapannya; 3) meningkatkan ketaatan terhadap pelaksanaan peraturan perundangundangan tersebut secara sukarela; dan 4) memperluas bentuk partnership dengan warga negara. Sedangkan dalam konteks pembuatan kebijakan publik, Sad Dian Utomo menyatakan bahwa manfaat partisipasi adalah ${ }^{25}$ :

1. Memberikan landasan yang lebih baik untuk pembuatan kebijakan publik.

2. Memastikan adanya implementasi yang lebih efektif karena warga mengetahui dan terlibat dalam pembuatan kebijakan publik.

3. Meningkatkan kepercayaan warga kepada eksekutif dan legislatif.

4. Efisiensi sumber daya, sebab dengan keterlibatan masyarakat dalam pembuatan kebijakan publik dan mengetahui kebijakan publik, maka sumber daya yang digunakan dalam sosialisasi kebijakan publik dapat dihemat.

22 M. Hadjon, Keterbukaan Pemerintahan dalam Mewujudkan Pemerintahan Yang Demokratis", Pidato, diucapkan dalam Lustrum III Ubhara Surya dalam Griadhi dan Sri Utari, Partisipasi Masyarakat dalam Pembentukan Peraturan Daerah, http://ojs.unud.ac.id/ index.php/kerthapatrika/ article/view/3257/2336.

23 Yuliandri, Op.Cit.

24 Direktorat Harmonisasi Peraturan Perundang-Undangan, Panduan Pengharmonisasian, Pembulatan, dan Pemantapan Konsepsi Rancangan Peraturan Perundang-Undangan, (Jakarta: Kementerian Hukum dan HAM dan UNDP: Cappler Project, 2010), hlm. 69.

25 Sad Dian Utomo, Partisipasi Masyarakat dalam Pembuatan Kebijakan, dalam Griadhi dan Sri Utari, Loc.Cit. 


\section{Partisipasi Masyarakat dalam Pembentukan Undang-Undang yang Responsif.}

Karakter produk hukum dalam sebuah negara dapat dibedakan menjadi tiga tipe, yaitu produk hukum yang represif, otonom dan responsif. Menurut Nonet dan Selznick mengemukakan teori mengenai tiga tipe dasar hukum dalam masyarakat, yaitu sebagai pelayan kekuasaan represif (hukum represif), hukum sebagai institusi tersendiri yang mampu menjinakkan represi dan melindungi integritas dirinya (hukum otonom), dan hukum sebagai fasilitator dari berbagai respon terhadap kebutuhan dan aspirasi sosial (hukum responsif) ${ }^{26}$. Hukum represif adalah hukum yang mengabdi kepada kekuasaan dan tertib sosial yang represif, banyak mengandalkan penggunaan paksaan tanpa memikirkan kepentinganyangada dipihakrakyat. Perhatian utama hukum represif adalah dengan dipeliharanya atau diterapkannya tata tertib, ketenangan umum, pertahanan, otoritas dan penyelesaian pertikaian. Hukum otonom adalah hukum yang berorientasi pada pengawasan kekuasaan represif. Artinya, hukum otonom merupakan antitesa dari hukum represif. Sifatsifat yang paling penting dari hukum otonom adalah pertama, penekanan pada aturan-aturan hukum sebagai upaya utama untuk mengawasi kekuasaan resmi; kedua, adanya pengadilan yang dapat didatangi secara bebas, yang tidak dapat dimanipulasi oleh kekuasaan politik dan ekonomi, serta memiliki otoritas eksklusif untuk mengadili pelanggaran hukum baik oleh pejabat umum maupun individu-individu ${ }^{27}$. Sedangkan hukum responsif berorientasi pada hasil, pada tujuan-tujuan yang akan dicapai diluar hukum. dalam hukum responsif, tatanan hukum dinegosiasikan, bukan dimenangkan dengan cara sub ordinasi. Ciri-ciri hukum responsif adalah mencari nilai-nilai tersirat yang terdapat dalam peraturan dan kebijakan ${ }^{28}$. Hukum responsif menawarkan lebih dari sekadar procedural justice, namun lebih berorientasi pada keadilan dengan memperhatikan kepentingan umum. Teori ini lebih menekankan pada substantial justice. Persoalan keadilan lebih dipahami sebagai quid ius, bukan quid iuris. ${ }^{29}$

Adapun tolak ukur untuk melakukan evaluasi terhadap peraturan hukum responsif adalah asas atau prinsip serta tujuan yang ada dalam peraturan tersebut. Walaupun terlihal ideal dan positif, akan tetapi sebenarnya terdapat sisi negatif yang harus diwasapadai. LM. Gandhi menyatakan segi negatif yang harus disadari dari hukum responsif adalah bertumpuknya berbagai lembaga hukum dengan tujuan yang saling berbenturan dimana masing-masing lembaga tersebut mementingkan diri sendiri dengan visi dan sikap yang kaku sehingga menyulitkan dalam upaya harmonisasi. Kondisi ini akan dapat mengakibatkan pemerintah

26 A. Ahsin Thohari, Reorientasi Fungsi legislasi Dewan Perwakilan: Upaya Menuju Undang-Undang Responsif, Jurnal Legislasi Indonesia, Vol. 8 No. 4, (Jakarta: Direktorat Jenderal Peraturan Perundang-Undangan, 2011) hal. 569

27 M. Husni, Pemberdayaan Masyarakat Sebagai Upaya Penegakan Hukum, Jurnal Eqiuty, Vol 11, No. 2 Agustus 2006, hal.88-89 diakses dari http://isjd.pdii.lipi.go.id/admin/jurnal/112068693.pdf

28 A. Ahsin Thohari, Loc. Cit.

29 Rizal Mustansyir, Landasan Filosofis Mazhab Hukum Progresif: Tinjauan Filsafat Ilmu, http://progresif-lshp. blogspot.com/

30 L.M.Gandhi, Harmonisasi Hukum Menuju Hukum Responsif, Pidato Pengukuhan Jabatan Guru Besar Tetap pada Fakultas Hukum Universitas Indonesia 14 Oktober 1995, hlm. 3, diakses dari http://www.digilib.ui.ac.id digital_ files_disk1_222_jkptuipp-gdl-publ-1995-lmgandhi-11054-p19956a 


\section{$\mathrm{R}_{\text {juknaL }}^{\text {juTSVINDING }}$ \\ Media Pembinaan Hukum Nasional}

Volume 1 Nomor 3, Desember 2012

menjadi tidak berdaya, prioritas pembangunan tidak dapat ditentukan dan kepentingan umum menjadi terabaikan. ${ }^{30}$

Menurut Mahfud MD, indikator produk hukum responsif adalah 1) pembuatannya partisipatif, 2) muatannya aspiratif, dan 3) rincian isinya limitatif. Pembuatannya partisipatif mengandung arti bahwa dalam proses pembantukan undang-undang sejak perencanaan, pembahasan, penetapan hingga evaluasi pelaksanaannya memerlukan keterlibatan masyarakat secara aktif. Muatannya aspiratif mengandung arti bahwa materi atau substansi norma dalam undang-undang harus sesuai dengan aspirasi masyarakat. Sedangkan rinciannya isinya limitatif mengandung arti bahwa segala peraturan perundang-undangan yang merupakan peraturan pelaksanaan dari undang-undang yang dibentuk harus sesuai dengan makna darinorma dasaryangterkandung dalam undang-undang tersebut ${ }^{31}$. Sedangkan $A$ Thohari menyatakan bahwa hukum responsif hanya bisa dicapai melalui responsivitas di seluruh tahapannya, yaitu: ${ }^{32}$

1. Proses penggalian nilai-nilai dan aspirasi yang berkembang dalam masyarakat oleh penyelenggara negara yang berwenang merumuskan politik hukum.

2. Proses perdebatan dan perumusan nilainilai dan aspirasi tersebut ke dalam bentuk sebuah rancangan undang-undang oleh penyelenggara negara yang berwenang merumuskan politik hukum.

3. Penyelenggara negara yang berwenang merumuskan dan menetapakan politik hukum; dan

4. Faktor-faktor yang mempengaruhi dan menentukan suatu politik hukum , baik yang akan, sedang, dan telah ditetapkan.

Tim Pengembangan Kebijakan Nasional Tata Keperintahan yang baik menyatakan bahwa indikator minimal dalam proses partisipasi masyarakat adalah 1) adanya pemahaman penyelenggara negara tentang proses/metode partisipatif dan 2) adanya pengambilan keputusan yang didasarkan konsensus bersama. Adapun perangkat pendukung idikator tersebut adalah 1) pedoman pelaksanaan proses partisipatif, 2) mekanisme/peraturan untuk mengakomodasi kepentingan yang beragam, 3) forum konsultasi dan temu publik, termasuk forum stakeholders, dan 4) media mass nasional maupun media lokal sebagai sarana penyaluran aspirasi masyarakat. ${ }^{33}$

Dengan mendasarkan pada hubungan antara partisipasi masyarakat dan produk hukum yang responsif tersebut, maka untuk syarat utama untuk mendapatkan produk hukum yang responsip adalah membuka ruang untuk partisapsi masyarakat pada setiap tahapan pembentukan peraturan perundang-undangan. Dengan katalain harusada partisipasi masyarakat

30 L.M.Gandhi, Harmonisasi Hukum Menuju Hukum Responsif, Pidato Pengukuhan Jabatan Guru Besar Tetap pada Fakultas Hukum Universitas Indonesia 14 Oktober 1995, hlm. 3, diakses dari http://www.digilib.ui.ac.id digital_ files_disk1_222_jkptuipp-gdl-publ-1995-lmgandhi-11054-p19956a

31 Hendrik Hattu, Loc.Cit.

32 A. Ahsin Thohari, Loc.Cit.

33 Sekretariat Tim Pengembangan Kebijakan Nasional Tata Kepemerintahah yang Baik, Kementerian Perencanaan Pembangunan Nasional/Bappenas, Indikator Good Public Governance, 2007, diakses dari http://goodgovernance. bappenas.go.id/gg/file/ publications/ buku_indikator.pdf 
pada tahapan perencanaan, penyusunan, pembahasan, pengesahan atau penetapan dan pengundangan. ${ }^{34}$ Secara formal, partisipasi masyarakat dalam proses pembentukan undangundang dapat kita temukan dalam:

1) Pasal 96 UU No. 12 Tahun 2011. Apabila dibandingkan dengan ketentuan mengenai partisipasi masyarakat yang terdapat dalam UU No. 10 Tahun 2004, ketentuan yang tercantum dalam Pasal 96 UU No. 12 Tahun 2011 memang terlihat lebih rinci dan dapat berlaku pada setiap tahapan pembentukan undang-undang. Pengaturan dalam UU No. 10 Tahun 2004 menyatakan bahwa partisipasi masyarakat dilakukan dalam rangka penyiapan atau pembahasan rancangan undang-undang. Selain itu, untuk memperlancar proses partisipasi masyarakat tersebut, aturan dalam UU No. 12 Tahun 2011 memerintahkan agar setiap rancangan peraturan perundang-undangan harus dapat diakses dengan mudah oleh masyarakat.

2) Pasal 41 Perpres No. 68 Tahun 2005, dan

3) Pasal 208 sampai dengan Pasal 211 Peraturan DPR No. 1/DPR RI/I/2009-2010 tentang Tata tertib. ${ }^{35}$ Ketentuan dalam Pasal 96 UU No. 12 Tahun 2011 menggambarkan bahwa bentuk partispasi masyarakat dilakukan dengan memberikan masukan secara lisan/dan atau terlulis melalui rapat dengar pendapat umum, kunjungan kerja, sosialisasi dan atau seminar, lokakarya dan atau diskusi. ${ }^{36}$

Dengan mendasarkan pada tahapan pembentukan undang-undang yang dimulai dari tahap perencanaan sampai dengan pengundangan, maka partisipasi masyarakat dalam pembentukan undang-undang dapat dilakukan dengan tahapan:

34 Lihat Pasal 1 angka 1 UU No. 12 Tahun 2011 yang menyatakan Pembentukan Peraturan Perundang-Undangan adalah pembuatan Peraturan Perundang-Undangan yang mencakup tahapan perencanaan, penyusunan, pembahasan, pengesahan atau penetapan, dan pengundangan.

35 Selain mengatur tentang partisipasi masyarakat, Peraturan DPR No. 1/DPR RI/I/2009-2010 tentang Tata tertib tersebut juga mengatur mengenai Representasi Rakyat yang diatur dalam Pasal 203 sampai dengan Pasal 207. Dengan kerangka representasi rakyat tersebut, maka anggota dewan dalam satu daerah pemilihan dapat membentuk rumah aspirasi yang berfungsi untuk menerima dan menghimpun aspirasi masyarakat.

36 Merujuk Peraturan DPR No. 1/DPR RI/I/2009-2010, yang dimaksud dengan Rapat Dengar Pendapat Umum adalah rapat antara komisi, gabungan komisi, Badan Legislasi, Badan Anggaran, atau panitia khusus dengan perseorangan, kelompok, organisasi atau badan swasta, baik atas undangan pimpinan DPR maupun atas permintaan yang bersangkutan, yang dipimpin oleh pimpinan komisi, pimpinan gabungan komisi, pimpinan Badan Legislasi, pimpinan Badan Anggaran atau pimpinan panitia khusus (Pasal 239). Sedangkan kunjungan kerja dilakukan untuk melaksanakan representasi rakyat yang dilakukan untuk menyerap aspirasi rakyat di daerah pemilihan anggota (Pasal 203-204). 


\section{$\mathrm{R}^{\text {juenal }} \mathrm{ECHSVINDING}$}

Media Pembinaan Hukum Nasional

Tabel I: Partisipasi Masyarakat dalam Tahapan Pembentukan Undang-Undang

\begin{tabular}{|c|c|c|c|}
\hline Tahapan & Mekanisme & Pihak Yang Terlibat & Hasil \\
\hline $\begin{array}{l}\text { Perencanaan } \\
\text { Undang-Undang }\end{array}$ & $\begin{array}{l}\text { - Prolegnas Jangka } \\
\text { Menengah } \\
\text { - Prolegnas Prioritas } \\
\text { Tahunan }\end{array}$ & $\begin{array}{l}\text { BALEG DPR, Menteri Hukum dan HAM. } \\
\text { Berdasarkan usulan Kementerian/LPNK, } \\
\text { fraksi, komisi, DPD dan masyarakat }\end{array}$ & $\begin{array}{l}\text { Keputusan DPR } \\
\text { tentang Prolegnas RUU } \\
\text { Prioritas }\end{array}$ \\
\hline \multirow[t]{3}{*}{$\begin{array}{l}\text { Penyusunan } \\
\text { Undang-Undang }\end{array}$} & $\begin{array}{l}\text { - Penyusunan Naskah } \\
\text { Akademik }\end{array}$ & $\begin{array}{l}\text { RUU Prakarsa Pemerintah: } \\
\text { Kementerian/LPNK dengan pelibatan } \\
\text { unsur ahli, instansi terkait, perguruan } \\
\text { tinggi dan masyarakat disertai dengan } \\
\text { kegiatan sosialisasi untuk mendapat } \\
\text { masukan dari masyarakat } \\
\text { - RUU Prakarsa DPR: Anggota, komisi, } \\
\text { gabungan komisi, Badan Legislasi } \\
\text { dibantu badan fungsional dan } \\
\text { akademisi }\end{array}$ & Naskah Akademik \\
\hline & - Penyusunan RUU & $\begin{array}{l}\text { - RUU Prakarsa Pemerintah: Panitia } \\
\text { Antarkementerian yang terdiri dari } \\
\text { unsur kementerian/LPNK yang terkait } \\
\text { dengan substansi RUU dan ahli hukum } \\
\text { disertai dengan kegiatan sosialisasi } \\
\text { untuk mendapat masukan dari } \\
\text { masyarakat } \\
\text { - RUU Prakarsa DPR :Panitia kerja yang } \\
\text { terdiri dari Anggota, komisi, gabungan } \\
\text { komisi atau Badan Legislasi dibantu } \\
\text { badan fungsional dan meminta } \\
\text { masukan dari masyarakat }\end{array}$ & Draft RUU \\
\hline & - Hormonisasi & $\begin{array}{l}\text { - RUU Prakarsa Pemerintah: } \\
\text { Dikoordinasikan oleh Menteri Hukum }\end{array}$ & $\begin{array}{l}\text { Draft RUU hasil } \\
\text { harmonisasi }\end{array}$ \\
\hline \multirow[t]{2}{*}{ Pembahasan } & - Pembahasan TK. I & $\begin{array}{l}\text { Komisi, gabungan komisi, BALEG, panitia } \\
\text { khusus atau Badan Anggaran dalam rapat } \\
\text { bersama Menteri yang mewakili Presiden } \\
\text { dan DPD untuk RUU tertentu. Masyarakat } \\
\text { dapat memberikan masukan dengan } \\
\text { menyampaikan pokok-pokok materi yang } \\
\text { diusulkan baik secara tertulis maupun } \\
\text { dalam RDPU }\end{array}$ & $\begin{array}{l}\text { Draft RUU hasil } \\
\text { pembahasan Tk. I }\end{array}$ \\
\hline & - Pembahasan Tk. II & $\begin{array}{l}\text { Seluruh anggota DPR dan Menteri yang } \\
\text { ditugasi Presiden }\end{array}$ & $\begin{array}{l}\text { RUU yang sudah } \\
\text { disetujui DPR }\end{array}$ \\
\hline Pengesahan & & Presiden & $\begin{array}{l}\text { Undang-Undang } \\
\text { yang sudah disahkan } \\
\text { Presiden }\end{array}$ \\
\hline Pengundangan & & Menteri Hukum dan HAM & $\begin{array}{l}\text { Pengundangan dengan } \\
\text { penempatan dalam } \\
\text { Lembaran Ngara dan } \\
\text { Tambahan Lembaga } \\
\text { Negara agar setiap } \\
\text { orang mengetahuinya }\end{array}$ \\
\hline
\end{tabular}

Sumber: diolah dari berbagai peraturan perundang-undangan 
Dari tabel tersebut diatas, kecuali untuk proses pengesahan dan pengundangan, dapat terlihat bahwa masyarakat dimungkinkan untuk melibatkan dirinya dalam proses pembentukan undang-undang. Dengan demikian sebenarnya proses formal untuk mewujudkan produk undang-undang yang responsif sudah memungkinkan untuk dilaksanakan. Yang perlu disikapi selanjutnya apakah secara substansi, aspirasi masyarakat tersebut dapat diterima atau tidak oleh para pembentuk undangundang. Pengambilan keputusan terkait dengan substansi hukum tersebut sangat tergantung pada sikap dan cara pandang pembentuk undang-undang dengan berbagai kepentingan yang ada didalamnya. Pada tahapan inilah sebenarnya kualitas suatu undang-undang akan terlihat, apakah produk tersebut hanya akan dapat berlaku sebentar dan berguna untuk kepentingan sekelompok golongan saja ataukah mempunyai daya laku yang lama dan daya guna yang efektif untuk kepentingan seluruh lapisan masyarakat.

Partisipasi masyarakat tersebut dimungkinkan terjadi apabila didahului dengan langkah awal berupa ketersediaan akses informasi yang cukup terkait hal-hal yang diuraikan pada tabel diatas. Oleh karena itulah ketentuan dalam Pasal 96 ayat (3) UU No. 12 Tahun 2011 yang berbunyi "untuk memudahkan masyarakat dalam memberikan masukan secara lisan dan/ atau tertulis sebagaimana dimaksud pada ayat (1), setiap Rancangan Peraturan PerundangUndangan harus dapat diakses dengan mudah oleh masyarakat" menjadi sangat penting. Ketersediaan sarana komunikasi dan informasi menjadi faktor penentu utama untuk mewujudkan hal tersebut.

\section{E. Penutup}

\section{Kesimpulan.}

Partisipasi masyarakat dalam pembentukan peraturan perundang-undangan adalah merupakan wujud dari pelaksanaan asas keterbukaan yang merupakan salah satu asas dalam pembentukan peraturan perundangundangan yang akan memberikan manfaat penting dalam hal efektivitas pemberlakuan peraturan perundang-undangan di dalam masyarakat. Dalam suatu dalam suatu negara yang telah menganut sistem perwakilan, partisipasi masyarakat tetap diperlukan karena selain untuk mewujudkan pemerintahan yang demokratis juga diperlukan untuk mewujudkan masyarakat yang demokratis.

Secara formal, proses untuk mewujudkan produk undang-undang yang responsif melalui wujud partisipasi masyarakat sudah memungkinkan untuk dilaksanakan karena beberapa peraturan perundang-undangan yang mengatur mengenai tatacara pembentukan undang-undang sudah mengatur hal tersebut. Akan tetapi penerimaan aspirasi masyarakat secara substansi oleh para pembentuk undangundanguntukmewujudkan undang-undangyang responsif sangat tergantung pada sikap dan cara pandang pembentuk undang-undang dengan berbagai kepentingan yang ada didalamnya.

\section{Saran.}

Perlu adanya kesadaran dari masyarakat dan pembentuk undang-undang mengenai relasi yang terjadi diantara keduabelah pihak dalam pembentukan undang-undang. Masyarakat tidak hanya ditempatkan sebagai obyek pengaturan suatu undang-undang, tetapi harus menjadi aktor yang terlibat dalam pembentukan undangundang. Akan tetapi masyarakat juga tidak boleh 


\section{RECHTSVINDING \\ Media Pembinaan Hukum Nasional}

menjerumuskan pembentuk undang-undang untuk semata-mata memenuhi aspirasi atau kehendak kelompoknya karena pada akhirnya undang-undang akan berlaku untuk semua lapisan dan kelompok masyarakat.

Perlu adanya kemauan yang kuat dari pembentukundang-undanguntukmelaksanakan mekanisme partisipasi masyarakat. Kesadaran untuk membentuk undang-undang yang responsif yang mempunyai daya laku yang lama dan daya guna yang efektif untuk kepentingan seluruh lapisan masyarakat harus menjadi landasan bagi sikap dan cara pandang pembentuk undang-undang.

\section{DAFTAR PUSTAKA}

\section{Buku}

Badan Pembinaan Hukum Nasional Kementerian Hukum dan HAM, 2009, Laporan akhir Penyusunan Naskah akademik RUU Perubahan Atas UU No. 10 Tahun 2004 tentang Pembentukan Peraturan Perundang-Undangan, Jakarta

Direktorat Harmonisasi Peraturan PerundangUndangan, Direktorat Jenderal Paraturan Perundang-Undangan Kementerian Hukum dan HAM dan UNDP: Cappler Project, 2010, Panduan Pengharmonisasian, Pembulatan, dan Pemantapan Konsepsi Rancangan Peraturan Perundang-Undangan, , Jakarta.

Indrati, Maria Farida, Ilmu Perundang-Undangan: Jenis, Fungsi dan Materi Muatan (Yogyakarta: Penerbit Kanisius, 2002).

Thohari, A. Ahsin, Reorientasi Fungsi legslasi Dewan Perwakilan: Upaya Menuju Undang-Undang Responsif, Jurnal Legislasi Indonesia, Vol. 8 No. 4, Direktorat Jenderal Peraturan PerundangUndangan Kementerian Hukum dan HAM, Jakarta.

Yuliandri, Asas-Asas Pembentukan Peraturan Perundang-Undangan yang Baik: Gagasan Pembentukan Undang-Undang Berkelanjutan (Jakarta: Rajawali Pers, 2011).

Kurnia, Mahendra Putra Kurnia, dkk, Pedoman Naskah Akademik PERDA Partisipatif (Urgensi, Strategi, dan Proses Bagi Pembentukan Perda yang Baik) (Yogyakarta: Kreasi Total Media (KTM), 2007).

Soerjono Soekanto dan Sri Mamuji, Penelitian Hukum Normatif, Suatu Tinjauan Singkat (Jakarta: CV. Rajawali, 1990).

\section{Internet}

Gandhi, L.M, 1995, Harmonisasi Hukum Menuju Hukum Responsif, Pidato Pengukuhan Jabatan Guru Besar Tetap pada Fakultas Hukum Universitas Indonesia, Jakarta, diakses dari http://www.digilib.ui.ac.id digital_files_ disk1_222_jkptuipp-gdl-publ-1995-Imgandhi11054-p19956a

Griadhi dan Sri Utari, Partisipasi Masyarakat dalam Pembentukan Peraturan Daerah, diakses dari http://ojs.unud.ac.id/ index.php/ kerthapatrika/article/ view/3257/2336

Hattu, Hendrik, Tahapan Undang-Undang Responsif, Jurnal Mimbar Hukum, Vol. 23, No. 2, Juni 2011, Hal 406, diakses dari http://dosen. narotama.ac.id/wp-content/uploads/2012/02/ Tahapan-Undang-Undang-Responsif.Pdf

Husni, M, 2006, Pemberdayaan Masyarakat Sebagai Upaya Penegakan Hukum, Jurnal Eqiuty, Vol 11, No. 2 Agustus 2006 diakses dari http:// isjd.pdii.lipi. go.id/admin/jurnal/112068693. pdf

Kamus Besar Bahasa Indonesia, diakses dari http://www.kbbi.web.id/

Mustansyir, Rizal, Landasan Filosofis Mazhab Hukum Progresif: Tinjauan Filsafat IImu, http:// progresif-Ishp.blogspot.com/

Saifuddin, Proses Pembentukan UU: Studi Tentang Partisipasi Masyarakat dalam Proses Pembentukan UU, Jurnal Hukum No. Edisi Khusus Vol. 16 Oktober 2009 diakses dari http://law.uii. ac.id/images/stories/Jurnal\%20Hukum/5\%20 Saifudin. pdf

Sekretariat Tim Pengembangan Kebijakan Nasional Tata Kepemerintahah yang baik, 
Kementerian Perencanaan Pembangunan

Nasional/Bappenas, 2007, Penerapan Tata Keperintahan yang Baik, diakses dari http:// goodgovernance.bappenas. go.id/ gg/file/ publications/buku_hijau.pdf 2007, Indikator Good

Public Governance, diakses dari http:// goodgovernance.bappenas.go.id/gg/file/ publications/buku_indikator.pdf

\section{Peraturan}

Undang-Undang No. 12 Tahun 2011 tentang Pembentukan Peraturan Perundang-Undangan.

Peraturan Presiden No. 68 Tahun 2005 tentang Tata Cara Mempersiapkan Undang-Undang, Rancangan Peraturan Pemerintah Pengganti Undang-Undang, Rancangan Peraturan Pemerintah, dan Rancangan Peraturan Presiden.

Peraturan DPR No. 1/DPR RI/I/2009-2010 tentang Tata Tertib. 